\title{
125. Pseudopanolis takao, a New Genus and Species of the Noctuidae.
}

\author{
By Naomichi INABA.
}

Zoological Institute, Faculty of Agriculture, Tokyo Imperial University.

(Rec. June 29, 1927. Comm. by C. SASAKI, M. I. A., July 12, 1927.)

Included in the collection made at Mt. Takao, Musashi prefecture, and also in the Nikko region, in April and May, 1927, are found three males and two females of an interesting Noctuidmoth which appears to be new to science. This form, though having a close resemblance to the genus Panolis Hubner, stands at variance chiefly from it in the wings much longer and narrower as well as in the eyes larger and round. To me it seems that the differences are of sufficient value to separate the two forms generically.

Genus Pseudopanolis, nov.

Proboscis well developed; palpi short, porrect, and made up of two basal joints thickly haired and a terminal joints naked; frons smooth; antennae fasciculate in the male and ciliated in the female;

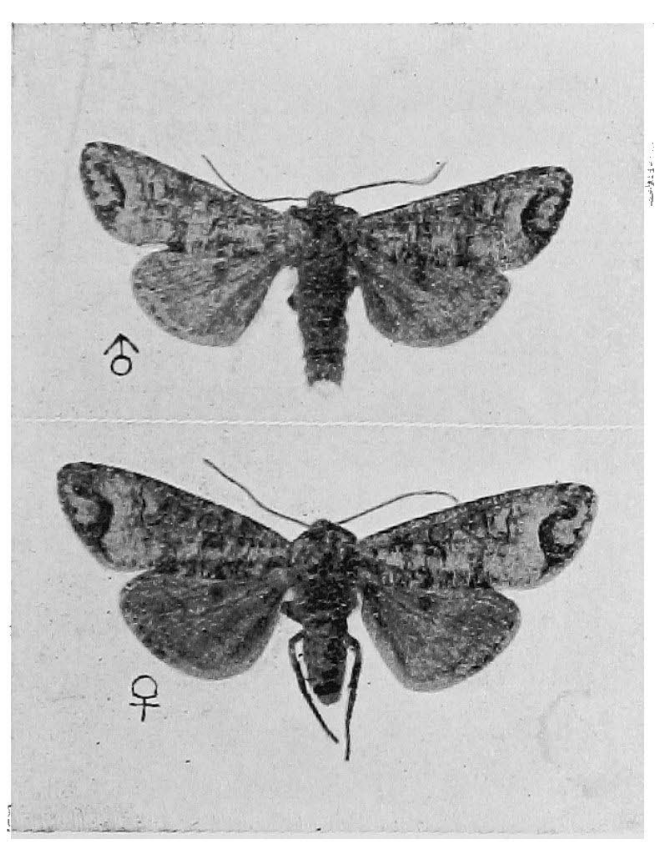

Text-fig. 1. Pseudopanolis takao, gen. et sp. nov., natural size. of male, of female. eyes large, round. Thorax clothed with hairs and hair-like scales mixed, without crest; femora hairy ; tibiae with two pairs of spurs; abdomen with a tuft of hairs at end. Fore wing with the apex rounded; $3,4,5$ from near angle of cell ; 6 from upper angle; 9 from 10 and anastomosing with 8 to form the areole. Hind wing with veins 3 , 4 , from angle of cell ; 5 obsolescent; 6,7 from upper angle; 8 anastomosing with the cell near base.

Pseudopanolis takao, sp. nov.

Head ochreous with the frons rufous; palpi rufous mixed with 
black and edged by white. Thorax whitish grey tinged with rufous at middle just behind the tegulae which are ochreous, greyish white at tips and have a double rufous line on them. Abdomen greyish brown, with an ochreous grey anal tuft. Fore wing whitish grey tinged with brown at middle, the proximal half of costal area and the inner marginal area pale green striated with black; subbasal line black, indistinct; antemedial line almost straight, black, indistinct; claviform defined by black at upper-margin only; orbicular defined by black, round ; reniform defined by black, more or less contracted at middle, filled in with brown at inner half; postmedial line black, indented between veins 1 and 2 ; subterminal line black, waved, curved out-

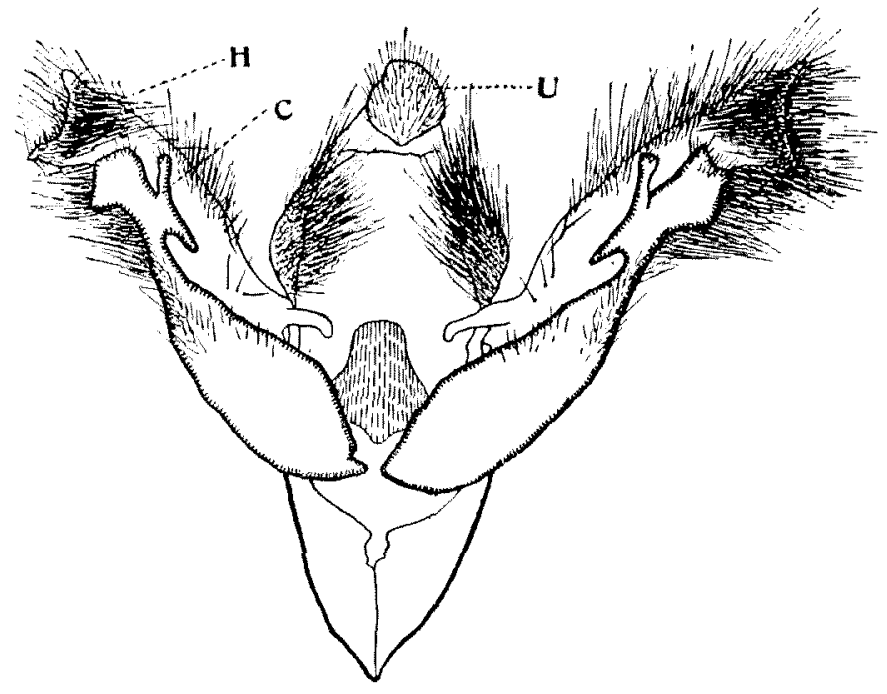

Text-fig. 2. Male genitalia. c. clasper, $h$. harpe, $u$ uncus.

wards at vein 7 and then inwards to vein 2 ; space exterior to the line between apex and vein 2 ochreous, interiorly well defined by a rufous line ; terminal line black mixed with rufous ; cilia rufous, whitish grey near tornus, and fuscous at middle. Hind wing wholly suffused with fuscous brown, with a faint curved subterminal line; cilia white with a slight touch of pink. Underside greyish white suffused on fore wing and irrorated on hind wing with fuscous; a blackish discoidal spot and a postmedial line on both wings.

Male genitalia. Harps bifurcated, thickly clothed with hairs; clasper in the sense of Pierce made up of elbowed hook; uncus broadly tongue-like in shape; vesica with strong teeth.

Expans, ô $37-40 \mathrm{~mm}$., o $42-44 \mathrm{~mm}$. 